\title{
PENGGUNAAN MEDIA PEMBELAJARAN DI MADRASAH ALIAH NEGERI SE-JAKARTA SELATAN
}

\author{
Rosita Primasari, Zulfiani, \& Yanti Herlanti \\ UIN Syarif Hidayatullah Jakarta
}

\begin{abstract}
This study aims to provide information that describes the use of instructional media used by biology teachers in the process of teaching and learning activities. This research conducted at five MAN of South Jakarta. The method of this research was survey. The sample consisted of five biology teachers and 153 students of grade X. The results of research showed that media are often used by teachers in classroom learning biology is ICT atau multimedia, media still image, and motion picture media, while the media is rarely used real media and movies with sound. Teachers consider the characteristics of biological concepts in determining the learning media.
\end{abstract}

Keywords: media, learning, instructional media, biology teachers

\begin{abstract}
Abstrak
Penelitian ini bertujuan untuk memberikan informasi yang menggambarkan tentang penggunaan media pembelajaran yang digunakan oleh guru biologi dalam proses kegiatan belajar mengajar. Penelitian ini dilakukan di lima MAN yang ada di Jakarta Selatan. Metode penelitian yang digunakan adalah metode survei. Sampel penelitian ini berjumlah lima orang guru biologi dan 153 siswa kelas X. Hasil penelitian yang didapat bahwa media yang sering digunakan oleh guru di kelas pada pembelajaran biologi adalah ICT atau multimedia, media gambar diam, dan media gambar gerak, sedangkan media yang jarang digunakan adalah media relia dan film dengan suara. Guru mempertimbangkan karakteristik konsep biologi dalam menentukan media pembelajaran.
\end{abstract}

Kata Kunci: media, pembelajaran, media pembelajaran, guru biologi.

\section{PENDAHULUAN}

Media dalam pembelajaran berfungsi memperjelas pesan yang disampaikan guru. Media juga berfungsi sebagai alat bantu mengajar (Sudjana \& Rivai, 2011). Media memudahkan siswa belajar, memberikan pengalaman konkrit, menarik perhatian, mengaktifkan indera siswa, dan membangkitkan dunia teori dengan realitanya.

Namun pada kegiatan belajar mengajar, guru tidak selamanya dapat membawa siswa pada objek yang sebenarnya terjadi ataupun sebaliknya, maka diperlukan media untuk membantu guru dalam pembelajaran. Media pembelajaran berfungsi untuk menghadirkan objek yang tidak dapat dilihat siswa secara langsung atau obyek yang terlalu mikro untuk dapat dilihat langsung, misalnya memperbesar benda yang kecil, menyajikan peristiwa yang letaknya jauh, kompleks, rumit, yang berlangsung dengan sangat cepat atau lambat, menjadi lebih sistematik dan sederhana (Susarno, 2010).

Penggunaan media pembelajaran harus bervariasi, menarik perhatian, lebih menyenangkan, dapat memberikan pengalaman belajar sehingga peserta didik dapat menangkap materi pelajaran dengan mudah. Jenis-jenis media yang dapat digunakan dalam pembelajaran adalah media grafis (gambar, foto, bagan, poster, dan lain-lain), media tiga dimensi (model kerja, mock up, diorama, dan lain-lain), media proyeksi (slide, film, OHP, dan lain-lain), serta penggunaan lingkungan sebagai media pembelajaran (Sudjana \& Rivai, 2011).

Media pembelajaran dapat diklasifikasikan berdasarkan taksonomi media Edling, taksonomi Gagne, taksonomi Rudy Bretz, dan taksonomi Duncan. Berdasarkan taksonomi media, Gagne mengklasifikasikan jenis-jenis media berdasarkan fungsi pembelajaran yaitu media demonstrasi, penyampaian lisan, media cetak, gambar diam, gambar gerak, film dengan suara, dan mesin pembelajaran (Munadi, 2012).

Penggunaan media tercantum dalam Rencana Pelaksanaan Pembelajaran (RPP). RPP mencerminkan kegiatan yang dilakukan oleh guru dan siswa untuk mencapai kompetensi yang telah ditetapkan. RPP minimal memuat lima komponen yaitu tujuan pembelajaran, materi ajar, metode pembelajaran, sumber belajar (media pembelajaran), dan penilaian hasil belajar (Munadi, 2012). Oleh sebab itu, hendaknya guru dapat menimbang dan memilih media apa yang akan digunakan pada kegiatan mengajar-belajar. Guru harus memiliki kemampuan untuk 
mengintegrasikan media pembelajaran ke dalam rencana pembelajaran.

Kenyataannya, berdasarkan wawancara dengan guru di sebuah Madrasah Aliah penggunaan media dalam pembelajaran dirasakan sebagai beban kerja yang cukup berat oleh guru, sehingga banyak guru yang enggan menggunakan media. Berdasarkan hasil wawancara guru pada 3 sekolah menengah atas yakni di sebuah MA di Jakarta dan dua SMA di Depok menyatakan bahwa menggunakan media merepotkan, media pembelajaran yang dibutuhkan tidak tersedia di sekolah, dan merasa kurang kreatifitas dalam membuat media pembelajaran sendiri.

Menurut Agung (2005) terdapat sekurangkurangnya tujuh alasan guru tidak menggunakan media pembelajaran, yaitu media merepotkan, media canggih dan mahal, tidak bisa menggunakan media, media mengalihkan perhatian siswa dari belajar serius, tidak tersedia media pembelajaran di sekolah, guru terbiasa berceramah, dan penggunaan media belajar belum dihargai atasan.

\section{Pertanyaan penelitian}

1. Media apa yang paling sering digunakan oleh guru pada pembelajaran biologi?

2. Bagaimana penggunaan media dihubungkan dengan konsep biologi?

\section{METODE PENELITIAN}

Penelitian ini dilaksanakan di lima Madrasah Aliyah Negeri (MAN) yang terdapat di Jakarta Selatan dilaksanakan pada tanggal 2-23 Oktober 2013. Sebanyak lima guru mata pelajaran biologi kelas X dan 153 siswa di MAN se-Jakarta Selatan.

\section{HASIL DAN PEMBAHASAN}

\section{Frekuensi Penggunaan Media Pembelajaran}

Frekuensi penggunaan media pembelajaran oleh guru biologi dalam kegiatan belajar mengajar dapat dilihat pada Gambar 1.

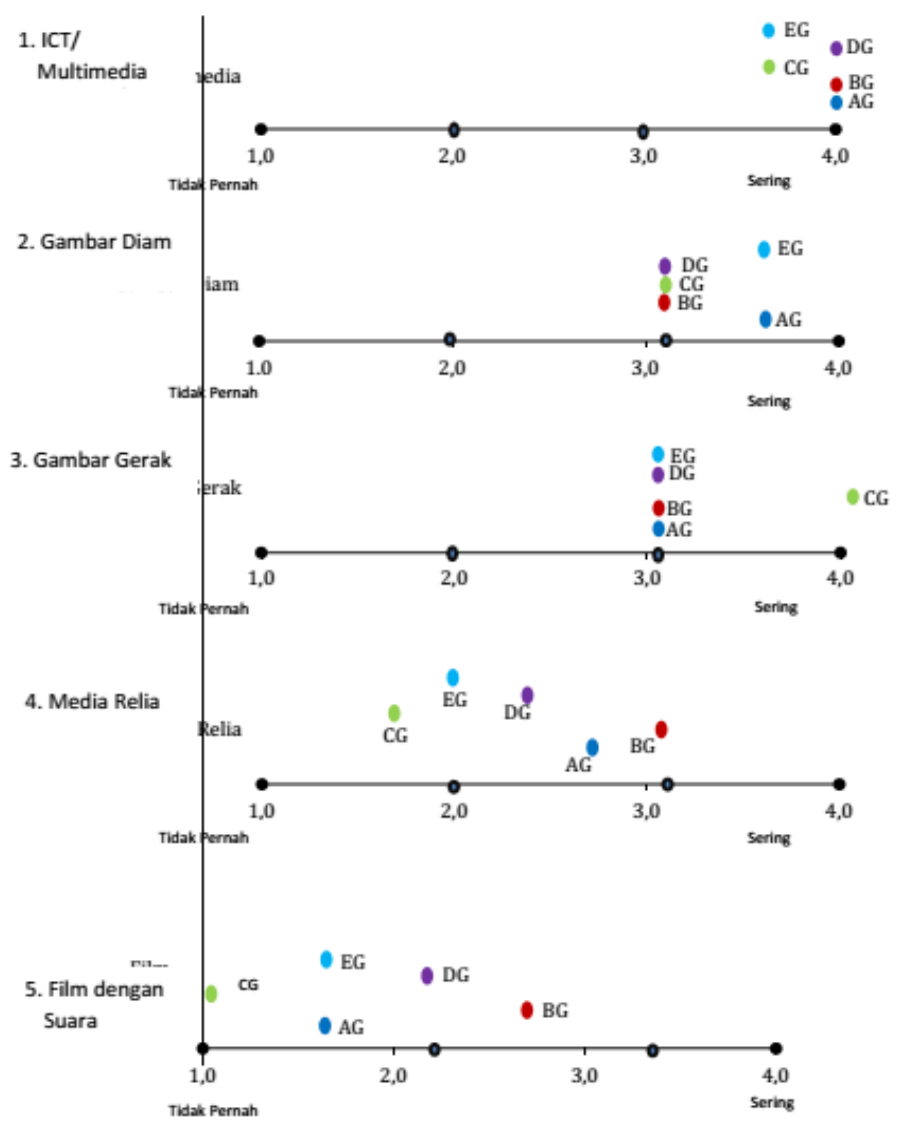

Gambar 1. Rerata Intensitas Penggunaan Media Pembelajaran 
Primasari, R., Zulfiani, \& Herlanti, Y.

Pada Gambar 1, terlihat bahwa media yang sering digunakan oleh guru yaitu media ICT atau multimedia, sedangkan media yang jarang digunakan yaitu media film dengan suara. Berdasarkan Gambar 1, penggunaan media ICT atau multimedia di lima sekolah tersebut sudah sering digunakan. Media gambar diam sudah sering digunakan di sekolah AG dan EG, sedangkan di sekolah BG, CG, dan DG, media tersebut kadangkadang digunakan. Media gambar gerak sering digunakan hanya di sekolah CG, sedangkan untuk di empat sekolah lainnya, media tersebut kadangkadang digunakan. Media relia jarang digunakan di sekolah CG, EG, dan DG, sedangkan di sekolah AG dan BG media tersebut kadang-kadang digunakan. Media film dengan suara tidak pernah digunakan di sekolah AG, CG, dan EG, sedangkan di sekolah BG dan DG media tersebut jarang digunakan.

Urutan media yang digunakan oleh guru dari yang paling sering digunakan sampai yang jarang digunakan adalah ICT atau multimedia, gambar diam, gambar gerak, media relia, dan film dengan suara. Intensitas penggunaan media oleh guru dalam proses belajar mengajar berbeda-beda. Sekolah BG paling sering menggunakan media ICT atau multimedia, sedangkan sekolah $\mathrm{CG}$ yang jarang menggunakan media relia dan film dengan suara.

Persepsi siswa terhadap penggunaan media pembelajaran oleh guru disajikan pada Gambar 2. Pada Gambar 2, dapat dilihat bahwa media yang sering digunakan oleh guru dalam proses belajar mengajar yaitu media gambar gerak, sedangkan media yang jarang digunakan oleh guru yaitu media relia. Urutan media pembelajaran yang digunakan oleh guru menurut siswa yaitu gambar gerak, gambar diam, ICT atau multimedia, film dengan suara, dan media relia.

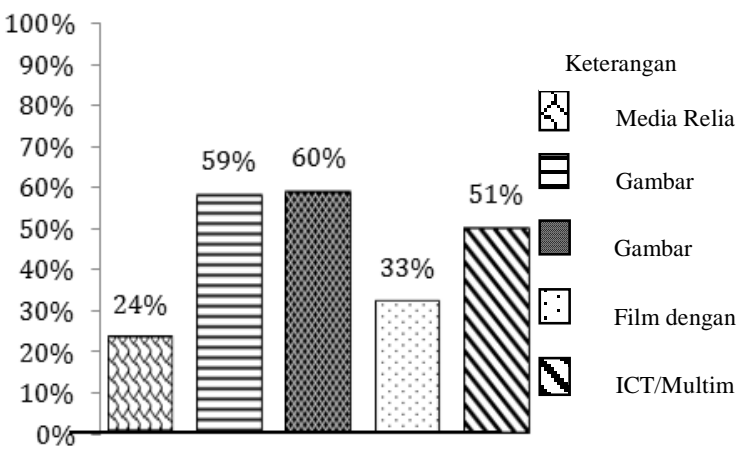

Gambar 3 Persentase Penggunaan Media Pembelajaran oleh Guru menurut Persepsi Siswa
Tabel 1 Urutan Penggunaan Media Pembelajaran menurut Persepsi Guru dan Siswa

\begin{tabular}{cll}
\hline $\begin{array}{c}\text { Urutan } \\
\text { ke- }\end{array}$ & \multicolumn{1}{c}{ Persepsi Guru } & \multicolumn{1}{c}{ Persepsi Siswa } \\
\hline $\mathbf{1}$ & ICT/Multimedia $\left.^{* *}\right)$ & Gambar Gerak $^{*}$ \\
$\mathbf{2}$ & Gambar Diam & Gambar Diam \\
$\mathbf{3}$ & Gambar Gerak & ICT/Multimedia \\
$\mathbf{4}$ & Media Relia & Film dengan Suara \\
$\mathbf{5}$ & Film dengan Suara & Media Relia \\
\hline
\end{tabular}

Keterangan:

*) Berdasarkan wawancara mendalam terhadap siswa, gambar gerak adalah animasi yang disajikan oleh guru dalam bentuk powerpoint.

**) Berdasarkan wawancara mendalam terhadap guru biologi, ICT atau multimedia adalah penggunaan powerpoint dalam menyampaikan materi.

Berdasarkan Tabel 1, dapat dilihat urutan penggunaan media pembelajaran yang digunakan oleh guru biologi dalam kegiatan belajar mengajar menurut persepsi guru dan siswa. Pada tabel ini terlihat bahwa guru menggunakan media dalam kegiatan belajar mengajar, yakni media yang sering digunakan adalah ICT atau multimedia, gambar gerak dan gambar diam. Sedangkan media yang jarang digunakan adalah media relia dan film dengan suara.

Berdasarkan Tabel 1, menurut persepsi guru, media yang sering digunakan adalah ICT atau multimedia, hal ini karena menurut responden media yang lainnya sudah termasuk ke dalam ICT atau multimedia dalam bentuk powerpoint, sedangkan menurut siswa media yang sering digunakan adalah gambar gerak yang disajikan dalam bentuk powerpoint. Menurut persepsi guru dan siswa, media yang jarang digunakan yaitu media relia dan film dengan suara. Hal ini karena disesuaikan dengan konsep pembelajaran yang telah diajarkan yakni pada konsep hakikat biologi, virus dan bakteri.

\section{Penggunaan media dihubungkan dengan konsep biologi}

Media pembelajaran perlu digunakan oleh guru memudahkan dalam penyampaian materi yang bersifat abstrak dan sulit menjadi materi yang dapat dimengerti oleh siswa, dan tidak terjadi miskonsepsi terhadap pengetahuan siswa. Untuk itu guru perlu membuat dan memilih media pembelajaran yang sesuai dengan materi yang akan disampaikan. 
Penelitian ini didasarkan pada hasil kuisioner yang telah diisi oleh responden yakni pada konsep hakikat biologi, konsep virus, dan konsep bakteri. Berdasarkan klasifikasi materi pembelajaran, konsep hakikat biologi dan virus termasuk ke dalam jenis materi yang bersifat fakta, konsep dan prosedur, sedangkan konsep bakteri termasuk ke dalam jenis materi yang bersifat konsep dan fakta.

Hakikat biologi merupakan materi pembelajaran yang bersifat konsep (konsep tentang perkembangan cabang-cabang ilmu biologi), bersifat fakta (fakta tentang sejarah perkembangan biologi), dan bersifat prosedur (langkah-langkah metode ilmiah). Virus merupakan materi yang bersifat konsep (konsep tentang struktur taksonomi, genus dan peranan virus), bersifat fakta (fakta tentang sejarah penemuan virus), dan bersifat prosedur (cara reproduksi virus). Bakteri merupakan materi yang bersifat konsep (contohnya tentang bentuk sel bakteri), bersifat fakta (contohnya tentang perkembangbiakan bakteri). Berikut ini disajikan Tabel 2 tentang tindakan guru dalam menggunakan media pembelajaran berdasarkan konsep biologi.

Berdasarkan Tabel 2 dapat dilihat bahwa penggunaan media pada proses KBM dan dalam kegiatan berdiskusi masing-masing telah mencapai $100 \%$ yakni digunakan pada konsep hakikat biologi, virus, dan bakteri. Sebanyak 87\% responden dapat mengadakan observasi diluar kelas pada konsep hakikat biologi, virus, dan bakteri. Serta $73 \%$ responden dapat memanipulasi benda untuk dijadikan media pada ketiga konsep tersebut. Selain itu juga diketahui bahwa pada masingmasing konsep, guru telah 90\% menggunakan media pembelajaran dalam proses belajar mengajar.

Masing-masing konsep disampaikan pada saat kegiatan pembelajaran dengan menggunakan media yang sesuai. Berikut ini akan disajikan Tabel 3 yang menjelaskan tentang penggunaan media pembelajaran sesuai jenis media pada konsep yang telah diajarkan oleh guru.

Berdasarkan Tabel 3 terlihat bahwa ICT atau multimedia mendominasi sebagai media pembelajaran yang sering digunakan oleh guru pada setiap konsep pembelajaran. Adapun media yang jarang digunakan pada masing-masing konsep tersebut adalah media film dengan suara.
Tabel 2 Persentase Tindakan Guru dalam

Menggunakan Media Pembelajaran berdasarkan Konsep Biologi

\begin{tabular}{|c|c|c|c|c|c|}
\hline \multirow[t]{2}{*}{ No. } & \multirow{2}{*}{$\begin{array}{c}\text { Indikator } \\
\text { Tindakan } \\
\text { Guru dalam } \\
\text { Mengguna- } \\
\text { kan Media } \\
\end{array}$} & \multicolumn{3}{|c|}{$\begin{array}{c}\text { Konsep Biologi } \\
\text { dalam }(\%)\end{array}$} & \multirow{2}{*}{$\begin{array}{c}\text { Rata- } \\
\text { rata } \\
(\%)\end{array}$} \\
\hline & & $\begin{array}{c}\text { Hakikat } \\
\text { biologi }\end{array}$ & $\begin{array}{l}\text { Viru } \\
\mathrm{s}\end{array}$ & $\begin{array}{c}\text { Bakter } \\
\text { i }\end{array}$ & \\
\hline 1 & $\begin{array}{l}\text { Media pada } \\
\text { proses } \\
\text { kegiatan } \\
\text { belajar } \\
\text { mengajar } \\
\text { (KBM) }\end{array}$ & 100 & 100 & 100 & 100 \\
\hline 2 & $\begin{array}{l}\text { Memanipulas } \\
\text { i benda untuk } \\
\text { dijadikan } \\
\text { media } \\
\text { pembelajaran }\end{array}$ & 60 & 80 & 80 & 73 \\
\hline 3 & $\begin{array}{l}\text { Observasi di } \\
\text { luar kelas }\end{array}$ & 100 & 80 & 80 & 87 \\
\hline 4 & $\begin{array}{l}\text { Media yang } \\
\text { digunakan } \\
\text { peserta didik } \\
\text { dalam } \\
\text { berdiskusi }\end{array}$ & 100 & 100 & 100 & 100 \\
\hline
\end{tabular}

Rata-rata

\begin{tabular}{l}
$90 \quad 90 \quad 90$ \\
\hline
\end{tabular}

Tabel 3 Persentase Penggunaan Media

Pembelajaran sesuai Jenis Media pada Konsep yang Sudah Diajarkan Guru

\begin{tabular}{|c|c|c|c|c|}
\hline \multirow[b]{2}{*}{ Jenis Media } & \multicolumn{3}{|c|}{ Konsep Biologi dalam (\%) } & \multirow{2}{*}{$\begin{array}{c}\text { Rata } \\
\text { rata } \\
(\%)\end{array}$} \\
\hline & $\begin{array}{c}\text { Hakikat } \\
\text { biologi }\end{array}$ & Virus & Bakteri & \\
\hline Media Relia & 18 & 15 & 13 & 15 \\
\hline Gambar Diam & 29 & 24 & 24 & 26 \\
\hline $\begin{array}{l}\text { Gambar } \\
\text { Gerak }\end{array}$ & 13 & 13 & 20 & 15 \\
\hline $\begin{array}{l}\text { Film dengan } \\
\text { Suara }\end{array}$ & 2 & 16 & 7 & 8 \\
\hline $\begin{array}{l}\text { ICT atau } \\
\text { multimedia }\end{array}$ & 35 & 53 & 53 & 47 \\
\hline
\end{tabular}

\section{PENUTUP}

Media yang sering digunakan oleh guru di kelas pada pembelajaran biologi adalah ICT atau multimedia, media gambar diam, dan media gambar gerak, sedangkan media yang jarang digunakan adalah media relia dan film dengan suara. ICT atau multimedia, gambar gerak, dan media relia paling banyak digunakan oleh guru 
biologi sebagai fungsi syarat eksternal, media gambar diam digunakan sebagai fungsi stimulus, sedangkan media film dengan suara digunakan sebagai fungsi alih kemampuan. Guru mempertimbangkan karakteristik konsep biologi dalam menentukan media pembelajaran.

\section{DAFTAR PUSTAKA}

Agung TW. 2005. Pendayagunaan Media Pembelajaran. Jurnal Pendidikan Penabur 4 (4): 80

Lamijan, Hadi Susarno LH. 2010. Strategi Penyampaian Bahan Ajaran Melalui Pemanfaatan Metode dan Media dalam Proses Pembelajaran. Jurnal Teknologi Pendidikan 10: 4.
Munadi Y. 2012. Media Pembelajaran. Jakarta: Gaung Persada Press.

Razak RA. 2013. Pembinaan Media Pengajaran Berasaskan Multimedia di Kalangan Guru ICTL. Jurnal Kurikulum dan Pengajaran Asia Pasifik 2(1) :30.

Rosmalia. 2007. Kesadaran Intuitif Guru Pendidikan Agama Islam terhadap Penggunaan Media dalam Pembelajaran", Skripsi UIN Syarif Hidayatullah Jakarta, Jakarta. tidak dipublikasikan.

Sudjana N, Rivai A. 2011. Media Pengajaran. Bandung: Sinar Baru Algesindo. 
Penggunaan Media Pembelajaran 